\title{
LIBERATED WOMAN IN BESSIE HEAD'S WHEN RAIN CLOUDS GATHER: A CRITICAL STUDY
}

\author{
Nargis Akhter, Arif Rashid Shah \\ Ph. D. Research Scholar, Department of English, \\ Jiwaji University, Gwalior, Madhya Pradesh, India.
}

\begin{abstract}
This paper attempts to explore women in the novel When Rain Clouds Gather by Bessie Head. When Rain Clouds Gather is about the liberation of women from the bondage of traditional society. The main liberator is Makhaya Maseko, who migrated from South Africa. Makhaya was also against the apartheid regime and he decided to start a new life in Botswana. Apart from Makhaya there was Mma-millipede who was also a migrant, Paul Sebina from the surrounding village, and Gilbert who was an immigrant from England.
\end{abstract}

Keywords: Bessie Head, When Rain Clouds Gather, Liberated, Education, Health, Economic Improvement, Women Empowerment, Immigrant.

\section{INTRODUCTION}

Head reveals that Makhaya was a man who had migrated from his country because he hated tribalism. He is educated and looked at things differently. As Dinorego mentioned, "It's only education that turns a man away from his tribe" (When Rain Clouds Gather, 1969,9).

Head uses Makhaya to reveal that women had sexual desires. Makhaya is embarrassed to "find the child looking at him with a full bold stare" (13). It is worse when the child further harassed him. Makhaya realized that the child is after money.

Makhaya, as a dignified man, distanced himself from child abuse and gave money to the child without intercourse. He further advised the child as an adult. The old woman did not believe that Makhaya had refused to sleep with her grandchild, as it was the case with most men. The old women enquired:

"You mean he gave you the money for nothing?" she said, beside herself with excitement." This is a miracle! I have not yet known a man who did not regard 
International Journal of Arts and Humanities

ISSN: 2581-3102

Volume: 04, Issue: 05 "May 2020"

women as a gift from God! He must be mad! Let us lock the door to protect ourselves from the mad man"! (15).

That gave the impression that Makhaya is handsome and, as a result, both men and women failed to resist their desires. That was verified by the fact that Maria, (Dinorego's daughter) is attracted by Makhaya even though she had an ongoing affair with Gilbert which had already lasted for three years. Makhaya's arrival made Maria reluctant to go to the farm for her lectures in English.

Maria's absences made Gilbert suspect that Makhaya might fall in love with Maria. This re sulted in an inferiority complex as he mentioned that:" I hope you don't love Maria too" (84). Prior to those words the situation was tense as Maria attracted Makhaya when he saw her for the first time.

Bessie Head introduces Paulina Sebina, as a woman who loved Makhaya without reservation. She felt herself to be the best woman among the women in the village, but she feared Maria because she thought that Maria might attract Makhaya. Head presents Gilbert as the mediator because he resolved the conflict by confronting Dinorego about Maria [his daughter].

Dinorego approves the marriage because Gilbert was as familiar to him as Makhaya, yet deep down in his heart he knew that he would have loved it if his daughter had married Makhaya.

The marriage between Maria and Gilbert paved the way for Paulina to avail herself of Makhaya without hesitation. Paulina initiated the relationship as follolvs: "She sends the greeting to Makhaya through her child"(78).

The response was contrary to what Paulina expected. Makhaya protested as follows: "Go and tell your mother I don't know her" (77). Those words sounded embarrassing to Paulina and as a result she visited Mma-millipede. Generally, women always relied on and depended on each other emotionally. Women told their friends about the problems they had with their kids, husband, their mothers and their in-laws.

Paulina told Mma-millipede that she loved Makhaya but she was disappointed by the feedback from her child. Mma-millipede consoled her, as she noted that:

The women of his country might have an entirely different approach when they wish to arouse the interest of a man (79).

Gilbert arranges his marriage with Maria. Paulina was ashamed yet joyful that this stumbling block had been removed. Head reveals Paulina's internal conflict during the marriage preparations. All women were happy about the event, but Paulina had an argument within herself 
International Journal of Arts and Humanities

ISSN: 2581-3102

Volume: 04, Issue: 05 "May 2020"

about how to disclose the secret to Makhaya. As a result she did not involve herself with the gossip about whether Makhaya was married because it was a sensitive issue on her side.

As a result she is ruled by her emotions and displayed jealousy when Grace Sebina mentioned that she had eyes to see that Makhaya was handsome. Paulina responded rudely as follows:

"If your eyes chase all the men, Grace Sebina," She said Crisply, "please don't put them on me "(92). All other Women stared at each other in shock. It was not polite to call a prostitute a prostitute in black and white terms (92).

This emotional outburst reveals that Paulina is absent minded even while she is trying to concentrate on her problem. Paulina migrated to Gomela Mmidi to escape discrimination by her husband's company, which confiscated all her property, after the death of her husband.

Paulina is underestimated as a woman because the company did not follow the court procedure. Paulina intended to start a new life in Gomela Mmidi with a special place for her new loved one. Paulina's dream became fulfilled when Makhaya changed his mind and introduced himself to Paulina. However, she is confused because he called her his wife before the formal proposal.

Makhaya's actions were due to the fact that he wanted both men and 'women to be equal. As such, Head created Makhaya as a hero who dedicated himself to the liberation of women's minds from the chains of tradition. As Aidoo said: "being a Woman is a position often defined in relation to serving the male" (Davies, 68).

Head intended the title of the novel When Rain Clouds Gather to be metaphorical. That is verified by the fact that there are no clouds in the sky literally. Figuratively speaking, the clouds are gathered in Paulina's heart. Paulina struggled by every possible means to reveal that she loved Makhaya.

Head reveals Paulina as an independent woman. This is verified by her strong words when she mentioned:

We who are here are the bravest; we are the only women who have smoked cigarettes and drink beer. That is why whatever we do the other women also do, though they are afraid to smoke and drink because they will be beaten by their husbands (116). 
International Journal of Arts and Humanities

ISSN: 2581-3102

Volume: 04, Issue: 05 "May 2020"

\section{REFERENCES}

Aidoo, A. African Writers Talk. Heinemann: London. 1972.

Davies, C. B. Beyond Boundaries Vol. 1.International Dimensions of Black Women's Writing. New York University Press: U.S.A. 1995.

Davies, C.B. Black Women, Writing and Identity: Migration of the Subject. Routledge: London. 1994.

Eilersen, G. S. Bessie Head: Thunder BehinQ Her Ears. Philip David Publishers Ltd : Southern Africa. 1995

Head, B. When Rain Clouds Gather. Gollancz: London. 1969.

Obbo, C. African Women their Struggle for Economic Independence. Ravan Press: Johannesburg. 1981 